\title{
Focusing on the Internal Environment in Discussion of the FCPA
}

\author{
Lauren M. Golick \\ Staff Accountant \\ Skoda Minotti \\ Elizabeth A. Janko \\ Risk Advisory Consultant \\ Ernst \& Young LLP \\ Scott A. Yetmar CMA, CFM, PhD \\ Associate Professor of Accounting \\ Cleveland State University
}

\section{Summary}

The Foreign Corrupt Practices Act (FCPA) of 1977 is a significant piece of American legislature that, especially in recent years, has been the subject of many heated debates in business discussions. As of February 23, 2017, this law has brought Department of Justice (DOJ) or Securities and Exchange Commission (SEC) actions in 497 cases, collected \$9,981,825,430 in total monetary sanctions imposed in all FCPA-related cases, and has ties to $\$ 4,279,568,195$ in bribery payments (Stanford Law School FCPA Clearinghouse, 2017).Recent years, relevant to the era of transformation in the regulatory and legal framework within the macro-environment, the demand for preventative and proprietary measures to implement effective internal controls for business enterprises has significantly increased. The FCPA is one of the internationally focused regulations in which is of high concern and risk for companies to comply with as indicative by the set forth standards and penalties if failure to comply. The FCPA can be analyzed in major core areas; penalties, international and domestic whistleblower provisions, and the socioeconomic status of countries combined with ethical development. Such three major discussion areas play a substantial role in determining the overall past history, current state, and future effectiveness of the FCPA. The FCPA has proven effective over the years, but in order for it to remain relevant and at the forefront of anticorruption and fair reporting, it must be updated to include increased standards for internal controls and software monitoring systems for large multinationals. The past successes of the FCPA, the unique role it plays as the world's first and foremost anti-corruption legislation, and the importance of the anti-corruption movement to human advancement in terms of improving the reliability of business financials; all contribute to the need for increased enforcement and continued modernization of the FCPA on the global front.

\section{History of the FCPA}

The current significance of the FCPA emanates from the same issues that propagated its establishment. As Mike Koehler relays in Volume 73 of the Ohio State Law Journal, the "discovery of the foreign corrupt payments problem in the mid-1970s resulted from a combination of work by the Office of the Watergate Special Prosecutor" (932). Illegal "slush funds" were found being used to distribute bribes and other illegal foreign payments, which caused further investigation into the reliability of the accounting records. The SEC report states that the goal of the investigation was not to determine if the foreign payments were illegal under U.S. law, but rather to investigate whether the payments should be disclosed to potential and current investors. This became a major issue in the foreign policy of U.S. companies that was furthered by the circumstances involving Gulf Oil, Northrop, Mobil Oil, and especially Lockheed (934). These companies had all made payments for a business purpose that were considered questionable to foreign parties. Lockheed was particularly important because of its status as the largest U.S. defense contractor and essentially owing its existence to federally-guaranteed loans (934). Koehler concludes that while "foreign policy was the primary policy concern from the discovered foreign corporate payments which motivated Congress to act...foreign policy was not the sole reason for motivating Congress. The legislative record also evidences that congressional motivation was sparked by a post-Watergate morality, economic perceptions, and global leadership" (938). 
There were essentially two main reasons why the FCPA was born. The scandals involving Watergate and Lockheed set the country into a frenzy for regulations regarding foreign policy on anti-corruption and triggered an overwhelming need to protect U.S. businesses and investors from unreliable records. Ethics, transparency, and anti-corruption are the pillars upon which the legislation was founded, and these pillars still remain intact and an integral part of the future of international business because of the FCPA's requirement of accurate accounting records and intolerance for bribery payments.

The true costs of corruption may not have been fully known in the 1970s when the foreign policy issue was first discovered and discussed, but after almost fifty years of implementing the FCPA and analyzing the results of world corruption, the results are staggering. The U.S. Department of Justice and the Securities and Exchange Commission released "A Resource Guide to the U.S. Foreign Corrupt Practices Act," which highlights the significance of corruption and how it is, now more than ever, a global problem. It negatively affects economic growth by averting resources from vital areas such as infrastructure, public health, and education, and it "undermines democratic values and public accountability and weakens the rule of law" (2) by harming American efforts in promoting democracy and freedom and in fighting poverty, crime, and terrorism all over the world (3). These are only the social downfalls; there are even more reasons how corruption is destructive to business. The DOJ and SEC list several reasons why: corruption is anti-competitive, it increases the cost of global business and inflates the price of government contracts in developing countries, and bribery undermines employee confidence while permitting other kinds of misconduct in the company atmosphere, such as employee embezzlement, financial fraud, and other types of harmful behavior (3). All of these costs of corruption rang true in the 1970s, and they are even more applicable in today's world of fast-spreading news, social media, and technological growth.

The Corruption Perceptions Index (CPI) 2016 shows exactly how much corruption exists in the world today, and it shows a staggering amount of highly corrupt countries, as evidenced by the color red:

\section{CORRUPTION PERCEPTIONS INDEX 2016}

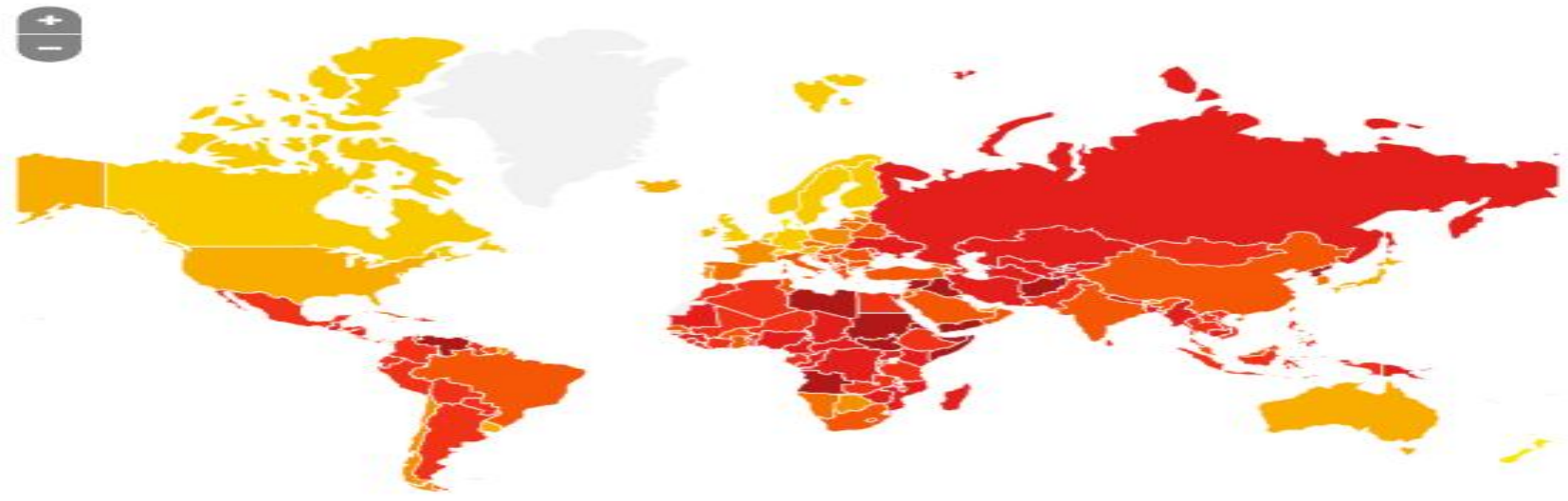

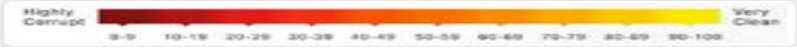 \\ Source: Corruption Perceptions Index 2016, Transparency International}

Economic well-being undoubtedly plays a large role in the perceptions index; first-world countries tend to have less corruption than undeveloped third-world countries. Therefore, countries with unstable governments also have high corruption rates. The economic and political situations of each country play a large role in determining its level of corruption, and that is why countries that is more stable, such as the U.S. and England, should step into the leadership role and lead the global fight against corruption.

\section{Provisions of the FCPA}

The events leading to the formation of the FCPA dictated the contents of the legislation. According to A Resource Guide to the U.S. Foreign Corrupt Practices Act, the intention of the law was "to halt those corrupt practices, create a level playing field for honest businesses, and restore public confidence in the integrity of the marketplace" (2). The first section of the FCPA covers the anti-bribery provision, which prohibits the exchange of something of value for the purpose of influencing an actor decision that would be advantageous for that individual or company (10). The FCPA applies to conduct within the United States as well as outside the country. 
The anti-bribery provisions apply to many different types of transactions, such as actions taken to ensure the winning of a contract, influencing certain processes, evading penalties, or obtaining exceptions, and it has been expanded to include bribes paid to obtain favorable tax treatment (13). By focusing on the intent of an entity rather than the action, the FCPA can penalize individuals and companies for intending to commit a corrupt act, as well as for committing the act (14). Corporations can also be held liable for bribes paid by subsidiaries if the parent company participated significantly in the illegal activity and if the parent exercises control under traditional agency principles (27). This is an intensely-debated subject matter, and one that costs multinationals millions of dollars in penalties if their subsidiaries are caught in illegal payment schemes.

The second section of the FCPA focuses on accounting provisions pertinent to public companies. According to $A$ Resource Guide to the U.S. Foreign Corrupt Practices Act, these provisions are meant to "strengthen the accuracy of the corporate books and records and the reliability of the audit process which constitute the foundations of our system of corporate disclosure" (38). There are two main categories to the accounting provisions section: books and records, and internal controls. The books and records section obliges issuers to maintain accurate records and accounts of the business in reasonable detail and accurately reflect the transactions of the entity (39). This part of the FCPA specifically addresses the requirement to accurately

Information source: "A Resource Guide to the U.S. Foreign Corrupt Practices Act," U.S. Department of Justice and U.S. Securities and Exchange Commission, 2016 record transactions and not disguise bribery payments as something legal, such as consulting fees or commissions. The internal controls section requires issuers to maintain a system of internal controls which ensures that transactions are accurate and that there is a segregation of duties (40). This part of the legislation focuses on the need to have strong internal controls to prevent fraudulent activity from occurring easily in a company, when one person might exercise too much authority over money or the accounting process.

If an individual or company is found to be in violation of the FCPA, there are very severe penalties of both a criminal and civil nature, which are depicted in the above table. With the magnitude of the penalties associated with violating the FCPA, companies must increase their employees' awareness of the legislation and improve internal controls so that the chances of employees engaging in illegal behavior diminish. The fines for participating in bribery or unethical accounting procedures can be extremely detrimental financially as well as socially for both businesses and individuals caught in illegal acts.

\begin{tabular}{|c|c|c|c|c|}
\hline $\begin{array}{l}\text { FCPA } \\
\text { VIOLATION } \\
\text { PENALTIES }\end{array}$ & $\begin{array}{l}\text { Anti-Bribery: } \\
\text { Civil }\end{array}$ & Anti-Bribery: Criminal & $\begin{array}{l}\text { Accounting Provisions: } \\
\text { Civil }\end{array}$ & $\begin{array}{l}\text { Accounting Provisions: } \\
\text { Criminal }\end{array}$ \\
\hline Individual & $\begin{array}{l}\text { - Fines up to } \\
\$ 16,000 \text { per } \\
\text { violation }\end{array}$ & $\begin{array}{l}\text { - Fines up to } \$ 250,000 \\
\text { - Imprisonment up to } 5 \\
\text { years }\end{array}$ & $\begin{array}{l}\text { - Cannot exceed the } \\
\text { greater of the gross } \\
\text { amount of the gain to } \\
\text { the defendant or a } \\
\text { specified dollar limit. } \\
\text { - Specified dollar limit: } \\
\$ 7,500-\$ 150,000\end{array}$ & $\begin{array}{l}\text { - Fines up to } \$ 5 \text { million } \\
\text { - Imprisonment up to } 20 \\
\text { years }\end{array}$ \\
\hline Corporation & $\begin{array}{l}\text { Fines up to } \\
\$ 16,000 \text { per } \\
\text { violation }\end{array}$ & - Fines up to $\$ 2$ million & $\begin{array}{l}\text { - Cannot exceed the } \\
\text { greater of the gross } \\
\text { amount of the gain to } \\
\text { the defendant or a } \\
\text { specified dollar limit. } \\
\text { - Specified dollar limit: } \\
\$ 75,000-\$ 725,000\end{array}$ & - Fines up to $\$ 25$ million \\
\hline
\end{tabular}

\section{Current Regulatory Environment}

The FCPA is an effective piece of legislation and is necessary to maintain and develop, so companies with unethical behavior are punished and suffer consequences for their actions; yet, the origin of the problem needs to be addressed. If weak internal controls are the problem, there should be a national focus on mandating a system that has strong internal controls. Inadequate supervision of subsidiaries should dictate a requirement for more transparent books and record from subsidiary to parent. 
The graph below depicts the amount of DOJ and SEC Enforcement Actions filed per year since 1977 (the year of the FCPA's inception). By interpretation of the provided chart below, the number of enforceable actions peaked in 2009 and has remained high since 2007. The importance of this legislation is founded in how it is applied, and its value is drawn from how well it protects U.S. businesses and consumers. The forecast for the next few years will likely consist of an increase in the amount of companies brought under the act's scrutiny while the DOJ and SEC crack down on companies and ensure compliance with ethical and legal behavior.

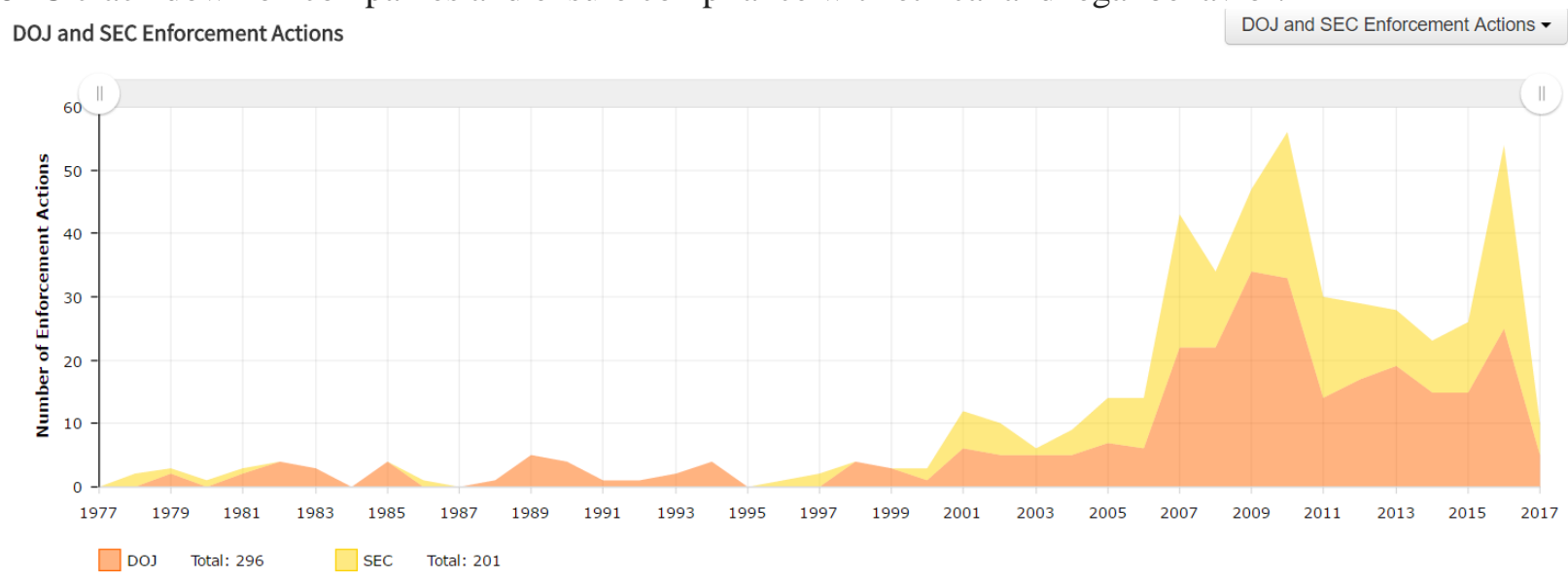

Source: FCPA Clearinghouse 2017, Stanford Law School

Total bribery payments have also risen, following the trend of increasing DOJ/SEC Enforceable Actions since 2007. As shown in the graph below, the number of bribes peaked in 2008 with the Siemens case, and since then there have been several years of large bribery payments, in 2008, 2010, and 2016. This upward trend can be expected to continue over the next few years. As the number of FCPA cases increase, the amount of total bribes will also increase.

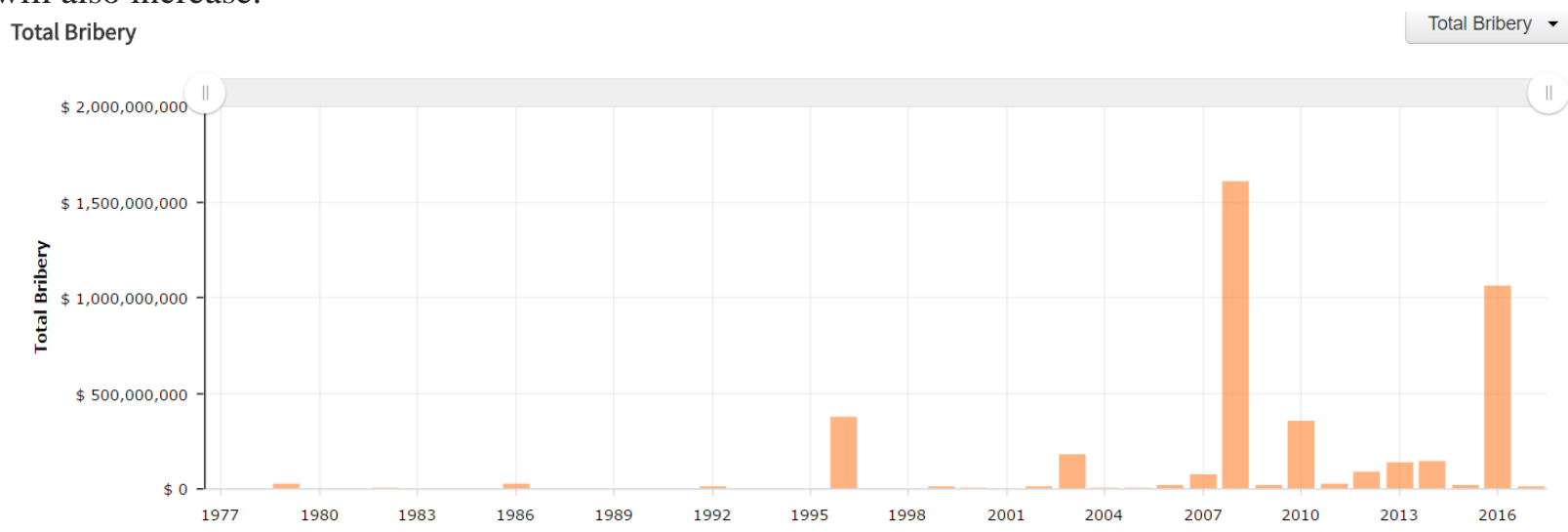

$\square$ Total Bribery Total: $\$ 4,279,568,195$

Source: FCPA Clearinghouse 2017, Stanford Law School

The need for more transparency in financial statements and better internal control monitoring for companies is rapidly pressuring regulators to either streamline regulation or revise current standards to keep up with the continuous development of the market. For example, the piloting and implementation of intelligent automation and artificial intelligence across diversified product to technology sectors tests how transactions should be analyzed and verified as reliant and material. Besides the significant variabilities involved in intelligent automation projects, determining the most effective strategy in centralized and de-centralized environments challenges regulators and business enterprises. It is percipient the theory of technology majorly transforming the internal control framework to detect and mitigate fraudulent transactions, but as indicative by current practices in Enterprise Risk Management (ERM), decreasing the amount and number of bribery payments is probable through effective risk management strategies. Utilizing transformative technology and aligned ERM strategies in the workplace will further establish accurate financial statements and reliable records towards a more optimal profitable enterprise for corporate management and investors. 


\section{COSO}

A significant amount of pressure and change in the internal environment of organizations is attributed to the emphasis on internal controls and fraud resilient frameworks. For example, in December 2014, the COSO 2013 Framework became effective and was implemented (COSO, 2017). "COSO" stands for Committee of Sponsoring Organizations of the Treadway Commission, which originally adopted, in 1992, a framework for basis to design and then test the effectiveness of internal controls (COSO, 2017). It was deemed necessary to update this more than 20-year old COSO Framework, as modified in 2013 and most recently in 2017, so that it provides a very supportable approach when adversarial third parties challenge whether a company has effective internal controls (COSO, 2017).Following internal control requirements under the FCPA, complying to the set forth requirements and standards by the DOJ and SEC can be modeled around the "COSO Cube" in which has core components outlining the structure in which organizations can formalize their internal control framework, ensuring compliance to regulatory standards (COSO, 2017). There is a direct relationship between objectives, which are what an entity strives to achieve, and enterprise risk management components, which represent what is needed to achieve them.

The compliance and enforcement paradigm shift for companies is affecting organizations in real time. For a historical example, in 2012, the SEC investigation on Oracle in processing unauthorized vendor payments in collusion with the Indian government to withhold \$2.2 million in unauthorized funds via fraudulent processing activities and invoices headlined world news. This ignited policy initiatives for streamlined practices of multinational organizations. The SEC's alleged that Oracle violated the FCPA's books and records provisions and internal controls provisions by failing to accurately record the side funds that Oracle India maintained with its distributors. Oracle failed in practice to maintain a system or proven strategy of effective internal controls that could have prevented the improper use of company funds.

At the same time that companies face new challenges in the design and implementation of internal controls, the government is heightening its scrutiny of company internal controls and raising the risks of civil and criminal prosecution of internal controls violations (SEC, 2012).

\section{ERM}

The highest regional FCPA concerns fall within the areas corruption and bribery in Nigeria, China, India, Indonesia, Mexico, Russia, Eastern Europe, and the Middle East. Globalization of business is partly responsible for the increased level of enforcement and transition of risk management practices. Enterprise Risk Management (ERM) is the method and processes organizations design through an operational framework to succeed their objectives. Through the emphasis on Sarbanes Oxley (SOX) of 2002, building a framework to calculate a reasonable structure of probable events and the response to potential threats across the entity can be designed through business and IT strategies unique to each organization. Bribery, collusion, money laundering, etc. cannot be easily anticipated and calculated when and how it would happen in complex organizations, but structuring an organization with clearly defined processing activities or management practices for example defines the controls set forth the risks associated to certain facets of a business enterprise. COSO and ERM have a mutual relationship when it comes to the design of the internal framework of a complex organization because the standards to the calculated risks fuels to implementation of a strong, effective internal environment more susceptible to safety and security risks of the organization.

\section{Future Outlook}

Centralizing focus on the internal environment through effective internal controls in ERM proves the future is optimistic for the enriching practice of the FCPA. The challenge to comply with the FCPA, as well as COSO framework design for internal controls, is worth the risk and reward in the ever changing internal and external environment in the diverse market front. The rapid development and growth of technology solutions offered in the market place challenges businesses to transcend into new opportunities offered through digital initiatives to secure high performance and reliable data for their internal environment. The FCPA was created to be unique, amended to be more effective, and currently pulls more than its weight in the benefits it plays in keeping businesses honest. The anti-corruption movement is an international fight, and by promoting international legislation that enforces strong internal frameworks of organizations by obtaining worldwide commitment to the cause, the FCPA will continue to flourish on its mission to create a more ethical and just society. 


\section{Works Cited}

Collins, Patrick, Lee Stein and Caryn Trombino. "Consider the Source: How Weak Whistleblower Protection Outside the United States Threatens to Reduce the Impact of the Dodd-Frank Reward Among Foreign Nationals.” PerkinsCoieLLP. https://www.perkinscoie.com/images/content/2/2/v2/22336/1025article.pdf.

“Corruption Perceptions Index 2016." Transparency International. http://www.transparency. org/news/ feature /corruption_perceptions_index_2016.

COSO. Enterprise Risk Management Integrating with Strategy and Performance: Executive Summary. The Committee of Sponsoring Organizations of the Treadway Commission, 2017, Enterprise Risk Management Integrating with Strategy and Performance: Executive Summary.

"Foreign Corrupt Practices Act Clearinghouse." Stanford Law School, a collaboration with Sullivan \& Cromwell $L L P$. http://fcpa.stanford.edu/.

Koehler, Mike. "The Story of the Foreign Corrupt Practices Act." Ohio State Law Journal 73, no. 5 (2012): 9291013.

"SEC Charges Oracle Corporation With FCPA Violations Related to Secret Side Funds in India." SEC.gov, SEC, 16 Aug. 2012, www.sec.gov/news/press-release/2012-2012-158htm.

"A Resource Guide to the U.S. Foreign Corrupt Practices Act." U.S. Department of Justice and U.S. Securities and ExchangeCommission.https://www.justice.gov/sites/default/files/criminal-fraud/legacy/2015/ 01/16/g uide.pdf.

Wolfe,Simon,Mark WorthSuelette Dreyfus,and AJ Brown."Whistleblower Protection Lawsin G20 Countries." Transparency International. September 2014.https://www.transparency .de/fileadmin/pdfs/ Themen/Hinweisgebersysteme/Whistleblower-Protection-Laws-in-G20-Countries-Priorities-for-Action .p df. 